\title{
Whither Taiwan: Ilha Formosa or Ilha Devastada?
}

\author{
Samuel L. Dunn ${ }^{1} \&$ Joshua D. Jensen ${ }^{1}$ \\ ${ }^{1}$ School of Business, Northwest Nazarene University, Nampa, Idaho, USA \\ Correspondence: Samuel L. Dunn, School of Business, Northwest Nazarene University, 623 S. University Boulevard, \\ Nampa, Idaho 83686, USA.
}

Received: August 1, 2018

Accepted: October 3, 2018

Online Published: October 11, 2018

doi:10.5430/ijba.v9n6p28

URL: https://doi.org/10.5430/ijba.v9n6p28

\begin{abstract}
Taiwan, formerly known as ilha Formosa (the beautiful island), and officially known today as the Republic of China, is an island situated approximately 250 kilometers off the east coast of China. The Republic of China has a population of 23.5 million and boasts the largest economy of any non-member of the United Nations. The People's Republic of China has continued to claim sovereignty over Taiwan, and refuses to engage in diplomatic relations with any nation that recognizes the Republic of China. United States policy toward Taiwan has been tentative and ambiguous, with inconsistent messages among various presidential administrations over the years. The question before the Republic of China and the People's Republic of China, and indeed, the entire world, is whether the Republic of China should become an independent country, become a fully integrated part of the People's Republic of China and come under the jurisdiction of Beijing, or continue to walk a middle road between these two alternatives. The authors propose that a date certain be set for reunification of Taiwan and China, and work begin to bring about an amenable resolution.
\end{abstract}

Keywords: Taiwan, Republic of China, People's Republic of China, reunification

\section{Introduction}

The Portuguese explorers who discovered it named it the ilha Formosa-the beautiful island. This island has certainly lived up to that name; it now supports 23 million people, a dynamic economy, and a vibrant democracy. But all is not well. For the country, now named the Republic of China $(\mathrm{RoC})$ and known as Taiwan, finds itself in a shaky position with respect to its neighbor 250 kilometers off its west coast-the People's Republic of China (PRC). The question before the RoC and the PRC, and indeed, the entire world, is whether the RoC should become an independent country, become a fully integrated part of the PRC and come under the jurisdiction of Beijing, or continue to walk a middle road between these two alternatives.

It is the authors' argument that the present relationship, the middle road, is untenable and unsustainable. Further, the RoC and the PRC, under the leadership of the United Nations, and with the support of the United States of America (U.S.), must move toward the reunification of the RoC with the PRC as soon as possible, all the while protecting the RoC's regional interests.

\section{The Present Situation}

The RoC, the PRC, and the United States are all suffering the consequences of the current state of affairs. Most problematic is the continuing threat of war over the RoC's status, with vast amounts of money the PRC spends on armaments to prepare for an invasion of Taiwan and the $\mathrm{RoC}$ spends to protect against such an invasion. The ever-present possibility of war takes a huge psychological and financial toll as well as inordinate amounts of time of government leaders who could better use personal skills and national resources to work on other societal problems facing the two regions. Further, thousands of men and women are tied up in armies, people whose skills and talents could be used for more productive ends.

The military situation is very dangerous with the threat of war blowing hot and cold. The RoC is maintaining a hair-trigger defensive system; its military strategists have discussed pre-emptive offensive strikes if the situation warrants. In 2011 the RoC held a live-fire test of its missiles during PRC President Hu's visit to the United States. On the other side, the PRC tests missiles, makes threats, and periodically conducts war-games in the Straits of Taiwan. "In the past year the Chinese armed forces have staged a growing number of exercises near Taiwan, including the flying of bombers and other aircraft around it" ("A Deadline Looms", 2018, para. 4). The PRC has up 
to 1600 ballistic and cruise missiles within range of Taiwan (Lowther, 2012). A half decade ago, the PRC passed a law which permits the PRC to intervene militarily if the RoC tries to become independent.

The RoC and the United States react to Chinese military activities by sending ships into the Straits of Taiwan, conducting their own war games, and obtaining more advanced armaments for the RoC. The RoC is mass-producing Hsiung Feng 2E cruise missiles, and it continues to enhance the range and effectiveness of its missile fleet today (Tien-pin \& Chin, 2017). Currently, the RoC has missiles that are capable of reaching the mainland ("Taiwan has Missile," 2013). According to a report from the Nuclear Threat Initiative,

The Taiwanese military is currently increasing and upgrading its ballistic missile defense capabilities, and by 2015 will have 10 batteries capable of firing either Patriot Advanced Capability (PAC)-2/GEM or PAC-3 missiles, with 32 PAC/GEMS or up to 128 PAC-3s per battery. Currently, Taiwan is beginning production of the Yun Feng, a mid-range missile with a range of $1,200 \mathrm{~km}$ that could eventually be extended to approximately 2,000 km. (Nuclear Threat Initiative, 2015)

\section{Potential Scenarios}

One way to forecast possible outcomes is through scenario planning. A scenario is a story about the future written in advance. Scenarios are used in a wide variety of contexts both for public policy planning purposes as well as for corporate business planning purposes. Scenario building helps identify potential risks and downfalls to proposed decisions. It helps to frame decisions and ultimately leads to better-informed decisions (Bowman, 2016).

The current context and developments along with historical contexts and events contribute to the development of future scenarios. "We cannot understand our current circumstances or assess future developments without the perspective that history and our own memory of the past can give us" (Cornish, 2004, p. 146). Scenarios help us to identify potential opportunities and threats to a number of potential situations or options, as they provide insight to help manage uncertainty and risk. "Risky decisions become more transparent and key threats and opportunities are identified" (Ringland, 2002, p. 4).

One can imagine various scenarios, both good and bad, focused on how the future may play out with respect to the PRC and the RoC. One possibility is that a war may be started without the intention of either authority. Scenario 1 describes such a situation.

\subsection{Scenario 1: Rogue Commander Initiates War}

Tokyo. March 3, 2020. PRC Controls Taiwan. After 11 days of fighting, the PRC government in Beijing announced on March 2 that military action against Taiwan ceased as of March 2 and Taiwan was now under PRC control. On March 1 Taiwanese authorities sued for peace and called all Taiwanese to lay down their arms. Japanese and U.S. military authorities estimated 21.5 million persons were killed in the war. Nuclear arms were not used and the United States did not intervene in the war. Military analysts believe the first strike in the war was a missile barrage on Taipei, Quemoy and Matsu from the Xiamen area (See Appendix A).

Another scenario is that war may be intentional. The flashpoint may be a declaration on the part of Taiwan to go independent. Scenario 2 describes this situation.

\subsection{Scenario 2: Nuclear War over Taiwan}

Washington, D.C. December 8, 2025. Over 98 Million Killed in Nuclear Interchange. China and the U.S. agreed to stop hostilities after a nuclear interchange that killed an estimated 98 million people in the PRC, the RoC, and the U.S. President Savid* of Russia is credited with starting negotiations which led to the stand-down. Casualties to date in the PRC are estimated at 55 million, in RoC at 8 million, and in the United States at 35 million. Cities devastated include Los Angeles and San Francisco in the United States, Shanghai, Xiamen, Fuzhou, Nanchang, Nanjing, Qingdao, and Zhongdu in the PRC, and Taipei and Kao-hsiung in the RoC. Fallout from the nuclear bombs is spreading west to east across the Pacific Ocean, across the United States and Canada into the northern Atlantic. Scientists estimate another 45 million people will die within the next year due to nuclear contamination (See Appendix B).

The future does not have to involve a war between the PRC and RoC. Scenario 3 considers a peace treaty.

\subsection{SINO Peace Treaty Signed in 2019}

Beijing. January 25, 2020. Historic Peace Treaty Signed. On this Chinese New Year's Day President Xi Jinping of the PRC and President Tang Shih-wen of the RoC signed a historic Sino Peace Treaty between the two governments. 
After 70 years of separation, mistrust, and enmity, the two countries have determined to enter the future with respect, trust, and hope, looking toward an eventual return of Taiwan to mainland control. President Xi is scheduled to travel to Taipei for a glorious festival on March 20, the day of the Spring Equinox.

The Treaty is not universally supported in Taiwan. Polls taken at the end of 2018 indicated that $15 \%$ of Taiwanese voters wanted Taiwan to declare independence from the PRC while another $20 \%$ wanted Taiwan to maintain its status as de facto independent but continued to support reunification at some point in the not-too-close future. Demonstrations against the Treaty were held in Taipei and Kaohsiung today. An estimated 90,000 people participated in the marches (See Appendix C).

\section{History of Relationship}

The current state of affairs began in the early 1970s with Henry Kissinger's and President Nixon's visits to China and the subsequent recognition of the PRC by the United States. In the Taiwan Relations Act of 1979, the United States promised support for the RoC. The United States agreed that Taiwan is part of China, but also guaranteed the RoC's de facto status as an autonomous state. The United States has stated that it is prepared to go all-out to protect the RoC's status and has put the RoC under its nuclear umbrella.

In 1982 President Reagan clarified then current U.S. policy toward the RoC in his famous "Six Assurances" (See Appendix D). President Clinton modified that stance through his "Three No's" statement of 1998 (See Appendix E). Altogether, U.S. policy toward the RoC and its relationship to the PRC is somewhat ambiguous and, some believe, contradictory. The policy leaves the United States in the peculiar position of saying yes and no at the same time. Further, if the situation were to deteriorate to the point that armed conflict would break out between the RoC and the PRC, the U.S. public might not support a military defense of the RoC. The public might not support the loss of U.S. lives to defend the independence of a province that the United States has already agreed should be part of China.

\section{Business Relationships Improving}

A further result of the status quo is the loss of economic and social potential on both sides of the Straits. While at the present time the $\mathrm{RoC}$ is among the top five sources of foreign direct investment on the mainland, the RoC could invest much more if better relationships prevailed. More investment in the PRC by the RoC could directly benefit the people on the mainland through jobs which are desperately needed by tens of millions of PRC workers. More investment would promote a longer sustained growth in China's GDP, would facilitate more transfer of technology and intellectual property, and would build stronger person-to-person human relations. A larger presence of Taiwanese on the mainland would have a subtle but real impact on political reformation on the mainland.

Recent signs of cooperation in the business sector appear promising. "President Ma (2008-2016) signed more than twenty pacts with the PRC, including the 2010 Economic Cooperation Framework Agreement (ECFA), a cross-strait agreement to lift barriers to trade (Albert, 2018). One of the agreements signed in 2014 erased restrictions on service industry cooperation. The following graph pictures the trade relationship between the mainland and Taiwan.

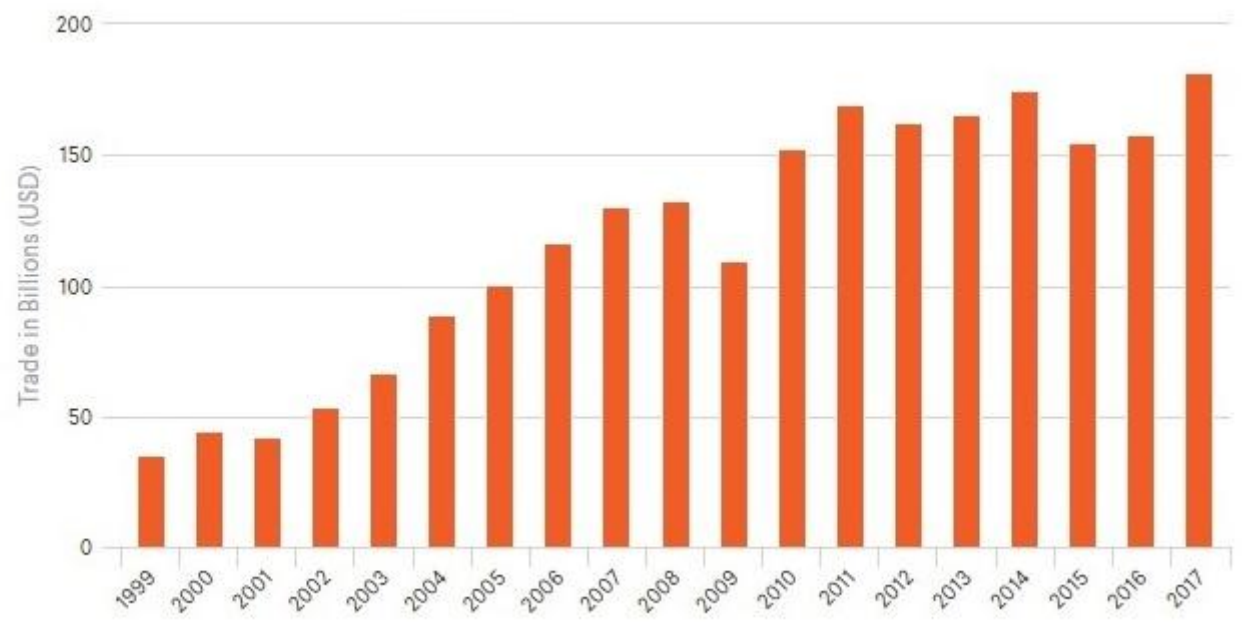

Figure 1. Trade between the people's republic of China (PRC) and the republic of China (RoC)

Source: Albert, 2018. 


\subsection{Data on the PRC and the RoC}

The following table provides key data about the two regions.

Table 1. Key data-the People's Republic of China (PRC) and the Republic of China (RoC)

\begin{tabular}{lll}
\hline & PRC & RoC \\
\hline Population & $1,379 \mathrm{~B}$ & $23.5 \mathrm{M}$ \\
Area (sq. km) & $9,596,960$ & 35,980 \\
Agriculture Land & $54.7 \%$ & $22.7 \%$ \\
GDP (Purchase Power Parity) & $\$ 23.12 \mathrm{~T}$ & $\$ 1.175 \mathrm{~T}$ \\
Per Capita GDP (PPP) & $\$ 17,000$ & $\$ 49,800$ \\
Population Below Poverty Line & $3.3 \%$ & $1.5 \%$ \\
Life Expectancy at Birth & 75.7 years & 79.98 \\
Literacy & $96.4 \%$ & $98.5 \%$ \\
Government Type & One party & Multiparty \\
& Dictatorship & Democracy \\
Capital & Beijing & Taipei \\
Military Expenditures (Percent of GDP) & $1.9 \%$ & $2 \% *$ \\
\hline
\end{tabular}

Source: World Factbook, 2018a; World Factbook, 2018b; *Strong, 2017

\section{Proposal}

Now is an opportune time to bring Taiwan and China together; later may be too late to prevent a war. The younger people of Taiwan do not have ties to the mainland that the older generation has; the younger people are more inclined toward complete independence from the mainland. As time goes by this inclination will increase and the decision to be independent might then be made. However, the mainland authorities have already passed a law stating that the mainland can go to war over an independent Taiwan. If the sentiment for independence prevails, then it is predicted that a war will ensue (Kupfer, 2018).

What to do about this predicament? Proposal: The United Nations shall take the lead in convincing the PRC and the RoC to accept a date certain when reunification will occur. To get the discussion started, it is proposed that the year 2040 be chosen as the year reunification will occur. This will give both the RoC and the PRC time to make the appropriate adjustments and build the relationships that will make the reunification feasible and desirable.

There are two models for this proposal. The first is the return of the Panama Canal to Panama. On September 7, 1977, President Carter signed the two treaties known as the Torrijos-Carter Treaties that set noon on January 1, 2000 as the date when control of the canal would be given to Panama. These Torrijos-Carter treaties replaced the 1903 treaty which gave control of the canal to the United States Between 1977 and 2000 there was much work done to prepare for the transfer of administration of the canal to Panama. The Panama Canal has thrived under Panama's control.

The second model for this proposal is the unification of Hong Kong with the PRC. In this case there was a treaty, finalized in December 1984, which aggregated the previous treaties and leases into one document which set a specific date, July 1, 1997, when control of Hong Kong would pass from the United Kingdom to the PRC. Knowing a specific date for transfer of power gave impetus to all three parties - Hong Kong, the United Kingdom, and the PRC - to prepare for a constructive and beneficial transfer. The special status granted to Hong Kong in the PRC has proven advantageous to most involved.

Taking such a similar decision for the RoC will not happen without the leadership of the United Nations and the explicit encouragement of the United States. Most likely, the United States will need to use some pressure to bring the $\mathrm{RoC}$ to accept such a goal. Less pressure will be needed to get the PRC to accept this goal and date, for under this eventuality the PRC would reach without much pain the objective it has held since Chiang Kai-Shek and the Kuomintang government fled to Taiwan in 1949.

Obviously, it would take several years to consummate the reunification. If an agreement could be signed by 2020 , the 2040 target date would give 20 years to make the changes needed on both sides of the Straits before the unification would be consummated. 


\subsection{Preparing for Unification}

This leads to a discussion of some of the changes that should be made during that 20-year preparation period to facilitate the transfer of authority from Taipei to Beijing. Many lessons can be learned from the transfer of Hong Kong to China finalized in 1997. Some of the most important steps that must be taken include the following:

\subsubsection{United Nations Leadership}

The United Nations should establish a Unification Commission, working under the Security Council, which would guide the reunification process. The Commission would coordinate and guide the negotiations leading to increased goodwill, cooperation, and eventual unification of the two authorities.

\subsubsection{Stand Down}

A most important early step would be an agreement between the RoC and the PRC to stand down their offensive weapons. The two sides would move to a more passive defense posture and then to a gradual downsizing of manpower and armaments.

After an initial period of trust building, there should be regularly scheduled visits of military leaders between the two regions. Naval ships will schedule visits to each other's ports. Over time, the militaries will conduct joint war games, and will, toward the end of the period, prepare to integrate the two military systems.

\subsubsection{Movement of People and Goods}

Both jurisdictions should further open their borders to the movement of people and goods between the RoC and the mainland. A free trade agreement to eliminate all inbound and outbound tariffs between the two regions should be put in place. Direct flights and shipping between cities and ports should be increased so that people can visit each other for business and tourist purposes. According to a 2014 report from The Economist, almost 3 million mainlanders visited Taiwan in 2013, so large movements of people have already begun ("Symbolism as Substance," 2014).

\subsubsection{Scholars, Students, and Universities}

Students from the RoC and the PRC should be allowed to matriculate in universities in either jurisdiction without hindrance. It would be helpful for the Ministries of Education to establish scholarship programs to send students to universities in the other jurisdiction. Scholars should be allowed to work on either side of the Straits. The PRC's Confucius Institute program should be extended to all major RoC universities.

\subsubsection{Banks}

The PRC will continue to strengthen its banking system so that its own citizens as well as people from the RoC and other countries can depend on solvent banks, international banking standards and practices, international standards for accounting, and bank safety. Both governments must let the Yuan and the Taiwan Dollar float freely in the world's currency markets.

\subsubsection{Investment}

Both sides should liberalize their investment laws to allow direct investment in and full ownership of businesses in the other jurisdiction. The RoC now allows investments in the PRC, a step in the right direction. Rules and regulations must be designed to allow easy movement of money, goods, and intellectual property between the RoC and the PRC. The red tape required to establish businesses must be reduced. The full spirit of cooperation pledged by the PRC's membership in the World Trade Organization must be realized. Listing of stocks and stock ownership must be fully opened to citizens of either region.

\subsubsection{Courts, Laws, and Contracts}

The PRC needs to continue its work of strengthening its independent courts, the enforcement of laws, and the recognition and enforcement of contracts. Citizens of the RoC need to have full access to the courts on the mainland and vice-versa. The $\mathrm{RoC}$ and the PRC should reciprocally proceed to recognize the legal judgments rendered by courts in the other jurisdiction. Both regions must continue to work to eradicate corruption from all levels of business and government.

\subsubsection{Constitution of the PRC}

Of concern to people in the West is the matter of human rights in the PRC, particularly freedoms of the press, religion, and freedom of assembly. It is clear that the PRC is much freer, in the sense of the democratic West, than it was in the first 50 years of its existence. The trend to more freedom is clear, and further economic development will 
lead to even more expressions of freedom. The PRC is slowly but surely improving the practice of law under its Constitutional umbrella. In the years leading up to the unification, as courts become stronger, the guarantees of the Constitution of the People's Republic of China will increasingly be enforced, and greater freedom will ensue. Chapter II of the Constitution will increasingly be realized in practice, particularly provisions regarding speech (Article 35), religion (Article 36), freedom of person (Article 37), criticism of the state (Article 41), scientific research, literary and artistic creation (Article 47), and gender equality (Article 48) ("Constitution of the People's Republic of China," 1982).

The RoC promulgated its Constitution in 1947 ("Constitution of the Republic of China," 1947). As part of the ramp up to unification, the two entities will need to integrate their Constitutions. By 2030, the two authorities should appoint a joint Constitution Commission which will be charged with developing a new Constitution for the unified regions.

\subsubsection{Interested Countries}

The possibility that the PRC and the RoC would unify may cause concern to neighboring countries, for some may fear it might release the PRC to military adventurism in the region. To this end, it would be good for the PRC and the $\mathrm{RoC}$ to use the Asia-Pacific Economic Cooperation (APEC) group as a regional sounding board for disseminating information and seeking advice about the transition to unification. APEC has in its membership most of the principal interested countries of the region, including the PRC, the RoC, and the United States.

Table 2. Membership, Asia-Pacific Economic Cooperation

\begin{tabular}{lll}
\hline Australia & Brunei Darussalam & Canada \\
Chile & People's Republic of China & Hong Kong, China \\
Indonesia & Japan & Republic of Korea \\
Malaysia & Mexico & New Zealand \\
Papua New Guinea & Peru & Philippines \\
Republic of China & Russia & Singapore \\
Thailand & United States & Vietnam \\
\hline
\end{tabular}

\subsubsection{Special Status for the RoC}

During the 20-year preparation period, a special status for the RoC must be negotiated, similar to but not an exact copy of the special status of Hong Kong. As Hong Kong is, Taiwan should be designated a Special Administrative Region.

\section{Leadership}

Bringing a solution of the type proposed will require bold leadership from the leaders of the United Nations, the PRC, the RoC, and the United States. Now may be an opportune time to begin talks, given the leaders now in place in these three countries.

The party which controls the presidency in the RoC is the Democratic Progressive Party (DPP). President of the RoC and leader of the DPP is Tsai Ing-wen. Born in 1956, Tsai is an attorney and is the first female President of the RoC. She is the first President to be of some aboriginal descent, and is unmarried. Tsai won the 2016 presidential election with $56.1 \%$ of the vote. Tsai's term ends in 2020 . Head of government is Premier Lin Chuan.

The President of the PRC is Xi Jinping, who took office in 2013. There are no term limits. President Xi has served the Communist Party of China (CPC) most of his career. He served as Governor of Fujian and Zhajiang Provinces. He then served on the Politburo Standing Committee and the Central Secretariat before being elevated to the Presidency. $\mathrm{Xi}$ is known to favor a strong China with increasing influence and power in the region and in the world. His ideology is encompassed in his "China Dream."

The November 2015 meeting of President Xi and former RoC President Ma in Singapore was a good sign of a growing positive relationship between the mainland and Taiwan. At the same time, however, there appears to be a growing opposition in Taiwan to unification, and it appears that President Tsai is not so favorable toward reunification. The proposal given in this paper needs the support of the United States. The elimination of one of the world's hot spots would be greeted by the world community with support and approval. Such a move would strengthen even further the relationship between the PRC and the United States A solution to the RoC-PRC problem 
would further the Peace, Prosperity and Security program of the United States. However, the accession of the RoC to China would be a difficult pill for many U.S. conservatives to swallow.

It is not known if President Trump would support the proposed solution to the Taiwan problem. However, President Trump, as a conservative, may be in a position similar to President Nixon as being seen as an upholder of U.S. values, and could bring his conservative constituency along with a decision to reunite Taiwan with the mainland.

The negotiations to establish a reunification treaty will require all the time remaining before President Trump completes his first term in January 2021. Nevertheless, now is the time to move before some event triggers a war, which most likely would turn the RoC into an ilha devastada and cause a forfeiture of peace for our friends, the Chinese on both sides of the Straits.

\section{Conclusion}

In conclusion, the current state of affairs between the PRC and RoC is not sustainable. It is the authors' argument that the present position of Taiwan is untenable and unstable. There are many scenarios that could be devised to help predict the future of the PRC and RoC. This paper includes a variety of scenarios that represent possible outcomes to this matter. Ultimately, a peaceful reunification of Taiwan and China, under the umbrella of the PRC, is a defensible and desirable outcome.

\section{References}

A deadline looms in China's battle with foreign firms over Taiwan. (2018, July). The Economist. Retrieved August 17, 2018, from https://www.economist.com/china/2018/07/05/a-deadline-looms-in-chinas-battle-with-foreign-firms-over-taiwn

Albert, E. (2018, June). China-Taiwan relations. Council of Foreign Relations. Retrieved August 17, 2018, from https://www.cfr.org/backgrounder/china-taiwan-relations

Bowman, G. (2016). The practice of scenario planning: An analysis of inter- and intra-organizational strategizing. British Journal of Management, 27(1), 77-96. https://doi.org/10.1111/1467-8551.12098

Constitution of the People's Republic of China. (1982, December). The National People's Congress of the People's Republic of China. Retrieved July 31, 2018, from http://www.npc.gov.cn/englishnpc/Constitution/node_2825.htm

Constitution of the Republic of China. (1947, December). Office of the President of the Republic of China. Retrieved July 31, 2018, from https://english.president.gov.tw/Page/93

Cornish, E. (2005). Futuring: The exploration of the future. Bethesda, MD: World Future Society.

Farley, M., \& Marshall, T. (1998, July). U.S., Beijing used ringer to put Taiwan on table. The Los Angeles Times. Retrieved July 31, 2018, from http://articles.latimes.com/1998/jul/01/news/mn-65406

Kupfer, T. (2018, June). Taiwan's challenge. National Review, 70(12), 20-22. Retrieved August 17, 2018, from https://www.nationalreview.com/magazine/2018/06/25/taiwan-china-relations-identity-desired-despite-beijing/

Lowther, W. (2012, September). China practiced Taiwan attack: US media. Taipei Times. Retrieved July 31, 2018 from http://www.taipeitimes.com/News/front/archives/2012/09/23/2003543441

Nuclear Threat Initiative. (2015, June). Missile. Retrieved July 31, 2018, from http://www.nti.org/learn/countries/taiwan/delivery-systems/

Ringland, G. (2002). Scenarios in public policy. New York: Wiley.

Strong, M. (2017, October). Taiwan presents defense budget for 2018. Taiwan News. Retrieved July 31, 2018, from https://www.taiwannews.com.tw/en/news/3269913

Symbolism as substance. (2014, February). The Economist. Retrieved July 31, 2018, from https://www.economist.com/china/2014/02/15/symbolism-as-substance

Taiwan has missile that can reach mainland, ex-defence chief says. (2013, March). Retrieved July 31, 2018, from www.scmp.com/news/china/article/1192522/taiwan-has-missile-can-reach-mainland-ex-defence-chief-says

The "Six Assurances" to Taiwan. (1982, July). Formosan Association for Public Affairs. Retrieved July 31, 2018, from http://www.fapa.org/generalinfo/sixassurances.htm

The World Factbook. (2018a, July). The Central Intelligence Agency of the Unites States of America. Retrieved July 31, 2018, from https://www.cia.gov/library/publications/the-world-factbook/geos/ch.html 
The World Factbook. (2018b, July). The Central Intelligence Agency of the Unites States of America. Retrieved July 31, 2018, from https://www.cia.gov/library/publications/the-world-factbook/geos/tw.html

Tien-pin, L., \& Chin, J. (2017, December). Extended-range missiles ready for use. Taipei Times. Retrieved July 31, 2018, from http://www.taipeitimes.com/News/front/archives/2017/12/25/2003684599

Wortzel, L. (2000, March). Why the administration should reaffirm the "six assurances" to Taiwan. The Heritage Foundation. Retrieved from https://www.heritage.org/asia/report/why-the-administration-should-reaffirm-the-six-assurances-totaiwan

\section{Appendix A}

\section{Scenario 1: Rogue Commander Initiates War}

Tokyo. March 3, 2020. PRC Controls Taiwan. After 11 days of fighting the PRC government in Beijing announced on March 2 that military action against Taiwan ceased as of March 2 and Taiwan was now under PRC control. On March 1, Taiwanese authorities sued for peace and called all Taiwanese to lay down their arms. Japanese and U.S. military authorities estimated 21.5 million persons were killed in the war. Nuclear arms were not used and the United States did not intervene in the war. Military analysts believe the first strike in the war was a missile barrage on Taipei, Quemoy and Matsu from the Xiamen area.

\section{Background}

Liu Jintao* was fed up with the PRC's lack of action about Taiwan. Colonel Liu was a 43-year-old career military officer assigned to the Advanced Missile Action Brigade based in Xiamen. He and his squadron of military officers had been responsible for the last eight years for the 45 Diamond Head, non-nuclear missiles which were aimed at Taipei and its offshore islands. Over the years of his command Liu had gathered around him a squadron of officers and leaders who were personally loyal to him. Liu and his men had conducted, more times than he could count, war games in which his missiles were launched at various sectors of Taipei.

Liu was a member of the Xiamen cell of The East is Red, a super-nationalist organization which studied Chinese history, philosophy, and prospects for the future. Over the five years that Liu had been a member the Xiamen cell had gradually radicalized and had started to discuss ways in which they could assist the PRC in achieving its rightful place as the leading country of the world. In the last two years, conversations had turned to armed action as an avenue of assistance. While the party officials in Xiamen knew of the cell and its radicalization, provincial leaders viewed the group as harmless: all talk and no action.

However, Liu was different; he wanted to help and he didn't want to wait. From his perspective, the national leaders had dawdled for 70 years since 1949 when Chiang Kai-Shek had escaped the mainland and retreated to Formosa. It was clear to Liu that Formosa, now called Taiwan, was an integral part of the PRC and should not be left to thumb its nose at the greatest civilization in history.

Liu knew that the PRC had military superiority over the much smaller military of the RoC. The PRC had 2100 missiles pointed at Taiwan and its islands, while the RoC had 1500 missiles pointed back toward the mainland. The PRC's longtime intelligence program in Taiwan had pinpointed the locations of the RoC missiles; military doctrine asserted that most could be taken out with a first strike by PRC missiles. From Liu's perspective, the RoC practice of grouping its missiles together in pods of missiles made them extremely vulnerable.

What Liu's superiors did not know was that Liu, a missile engineer by training, had obtained the national command authority's launch codes. With his local launch codes, he had everything he needed to shoot his 45 missiles the 350 kilometers needed to take out about 1000 of the RoC missiles.

There would be great loss of life in a war between RoC and the PRC. Liu calculated that as many as 5 million Taiwanese would die, and perhaps as many as 10 million mainlanders. However, the war would not last long; the PRC would emerge victorious in just a few days. If the PRC struck first, and Taiwan retaliated, then the PRC would in turn retaliate and take out most of the rest of the RoC's missiles and devastate its naval and military installations. Chinese shock forces would be on the ground in Taiwan within one week and would take over the communications and water facilities and begin mop-up operations. The war would be over before the United States or the United Nations could make a decision to intervene. Since Liu was based in Xiamen, he knew that his base would be a target of RoC missiles. Liu might very well be killed, but it would be worth it to advance the eternal cause of the motherland.

The Chinese New Year in 2020 started on January 25 (by the Western Calendar). The celebrations would last 15 days to start the Year of the Rat. Liu decided to get the ball rolling on February 20, approximately 10 days after the 
close of the holidays. By then the country would be back to normal after the holidays and the military personnel would be back from their leaves. Liu would use his command authority and launch codes to send his 45 missiles flying toward selected targets in Taiwan, Matsu and Quemoy.

At midnight of February 20, Liu launched his 45 missiles. Over 1.5 million Taiwanese were killed in the initial non-nuclear onslaught. The great symbol of Taiwanese superiority, the Taipei 101 Tower, was destroyed. Approximately 790 of the Taiwanese missiles were knocked out, together with $45 \%$ of the Taiwanese navy and four main military installations on Taiwan.

RoC retaliated with 700 missiles, the remainder of its missile supply. Xiamen was obliterated, as were Fuzhou, Wenzhou, and Guangzhou. Two missiles hit Shanghai. Altogether 18 million people on the mainland were killed.

The PRC in turn retaliated by sending over 200 bombers from the mainland to knock out the remaining RoC military installations and key government installations. Another 2 million Taiwanese were killed. By the evening of February 22 , the command authority of the RoC military was destroyed. By February 25, the PRC had 125,000 soldiers on the island who took over all communications networks, all hospitals, and all water supplies. By March 1, the remaining leaders of the RoC sued for peace and called on all Taiwanese to lay down their arms.

Liu did not live to see the results of his work. His entire installation was eliminated by a direct hit from one of the RoC missiles in the early morning of February 21.

The United States did not retaliate. President Rensalleer* determined that U.S. policy had always been that Taiwan was part of the PRC; it would be foolhardy to stop the inevitable now that Taiwan was effectively under PRC control.

*Fictitious Names

\section{Appendix B}

\section{Scenario 2: Nuclear War over Taiwan}

Washington, D.C. December 8, 2025. Over 98 Million Killed in Nuclear Interchange. China and the United States agreed to stop hostilities after a nuclear interchange that killed an estimated 98 million people in the PRC, the RoC, and the U.S. President Savid* of Russia is credited with starting negotiations which led to the stand-down. Casualties to date in the PRC are estimated at 55 million, in RoC at 8 million, and in the United States at 35 million. Cities devastated include Los Angeles and San Francisco in the United States, Shanghai, Xiamen, Fuzhou, Nanchang, Nanjing, Qingdao, and Zhongdu in the PRC, and Taipei and Kao-hsiung in Taiwan. Fallout from the nuclear bombs is spreading west to east across the Pacific Ocean and to the United States and Canada. Scientists estimate another 45 million people will die within the next year due to nuclear contamination.

\section{Background}

Over the decade starting in 2010 the economy of Taiwan continued to prosper. The standard of living continued to increase for its 30 million citizens, and by 2020 Taiwan was relisted by the United Nations as a developed region. Taiwan continued to develop as a science and technology center and significantly increased its trade with other countries, including the PRC. By 2018 Taiwan was among the top five countries with the most Foreign Direct Investment in the PRC, and each year millions of visitors from Taiwan and the PRC visited across the Straits of Formosa.

The situation in the PRC was not so rosy. After years of significant growth the economy of China began to deteriorate. Millions of people were still moving to the cities, but the promise of the good life did not materialize. Riots were endemic in the major cities and the government did not seem to be able to satisfy the public. There were more and more calls that the Communist Party of China relax its control and allow more democracy.

While the citizens of Taiwan enjoyed good person-to-person relationships with people in the PRC, the Taiwanese were increasingly nervous about uniting with the mainland. Although the Kuomintang Party, which favored closer ties with the mainland, had held the presidency beginning in 2008, the election of 2016 brought to the presidency Tsai Ing-wen of the Democratic Progressive Party, who advocated for a more independent Taiwan. In 2020 the Kuomintang Party won again bringing to the presidency Li Ziang*, who advocated a completely independent Taiwan. Li's position was of deep concern to the PRC leadership, who regularly repeated that Taiwan would never be allowed to become independent.

After Li's election, the RoC began to work toward independence. Li's rhetoric raised tensions between the PRC and RoC. By May 2025, the militaries on both sides of the Straits moved to full alert status, and training was accelerated among all branches of the two militaries. The United States sent three of its advanced Ohio-class nuclear submarines 
and two aircraft carriers to the South China Sea, and located a second squadron of B-1 bombers at the U.S. base in Okinawa. The submarines, known as Big Boomers, each carried 24 Trident III ballistic missiles; each missile carries 10 warheads which are independently targetable.

On September 8, 2025 President Li reported to U.S. President Williams* that he would declare the RoC to be a nation independent of the PRC on October 1. President Williams attempted to dissuade Li, to no avail. President Li made the announcement on October 1. Immediately thereafter, the U.S. military was placed on DefCon2 status.

On October 15 the PRC warned the RoC that independence was not an option and that the PRC would attack the RoC and return Taiwan to PRC control. The warning did not deter President $\mathrm{Li}$, so both sides continued to gear up for war.

The PRC attacked on December 2. It immediately overran Quemoy and Matsu, lobbed 85 non-nuclear missiles on Taiwan, and followed up with an armada carrying 300,000 ground troops. The Taiwanese military proved to be more resistant than the PRC military leaders had counted on, so on December 4 the PRC dropped one 20-kiloton nuclear bomb on Kao-hsiung at the southern tip of Taiwan. Eight million people in southern Taiwan died within five days.

The PRC going nuclear brought the United States into the fight on December 5. Nuclear missiles from U.S. submarines hit Shanghai, Xiamen, Fuzhou, Nanchang, Nanjing, and Qingdao, all cities on the east coast of the PRC. The PRC retaliated with its ICBM force targeting cities in western U.S. War Eagle III satellites used laser technologies to disable 11 of the PRC's military communication satellites, seriously compromising the PRC's communication and command capabilities. In addition, the U.S. missile shield brought down most of the missiles incoming to the United States, but two nuclear missiles got through to Los Angeles and one to San Francisco. Casualties in Los Angeles and San Francisco alone were estimated to be 23 million people.

After the intercontinental exchange of nuclear missiles, cooler heads at the United Nations and other principal countries began to be involved in discussions trying to bring the hot war to a close. President Savid* of Russia prevailed on the Presidents of the PRC and the United States to halt nuclear attacks. United Nations Secretary General Jesus Rigozetta negotiated a cease-fire among the United States, the PRC, and the RoC.

All parties realized that the impact of the war would be felt for at least 150 years. Regions of 75 kilometers radius around Los Angeles and San Francisco will be uninhabitable for decades, as will similar regions around the cities hit in China. Nuclear fallout will be blown around the northern hemisphere; scientists estimate another 45 million people will die from nuclear contamination in the first year after the war.

*Fictitious Names

\section{Appendix C}

\section{Scenario 3: SINO Peace Treaty Singed in 2019}

Beijing. January 25, 2020. Historic Peace Treaty Signed. On this Chinese New Year's Day President Xi Jinping of the PRC and President Tang Shih-wen of the RoC signed a historic Sino Peace Treaty between the two governments. After 70 years of separation and enmity, the two countries determined to enter the future with respect, trust, and hope, looking toward an eventual return of Taiwan to mainland control. President $\mathrm{Xi}$ is scheduled to travel to Taipei for a glorious festival on March 20, the day of the Spring Equinox.

The Treaty is not universally supported in Taiwan. Polls taken at the end of 2018 indicated that $15 \%$ of Taiwanese voters wanted Taiwan to declare independence from the PRC, while another $20 \%$ wanted Taiwan to maintain its status as de facto independent but should continue to support reunification at some point in the not-too-soon future. Demonstrations against the Treaty were held in Taipei and Kao-hsiung today. An estimated 90,000 people participated in the marches.

\section{Background}

The Sino Peace Treaty did not come easy. Each government has regularly spent billions of dollars developing armaments to ward off attack by the other authority. In recent years each government has spent $2 \%$ to $3 \%$ of its Gross National Product to support its military. On the Taiwan side almost all the spending was dedicated to protect Taiwan from an invasion from the mainland. On the other side of the Straits of Formosa, the mainland government was determined that Taiwan would not declare itself to be a nation independent of the mainland; the PRC was ready to go to war to assure that the tie with the mainland would be maintained.

By 2018, the PRC had over 2000 missiles pointed at Taiwan and Taiwan's associated islands; 100 of those were tipped with nuclear weapons. The RoC had built up its missile capability with over 1500 missiles pointed toward the 
mainland. All of the RoC missiles carried conventional warheads, but the RoC depended on the United States to support the RoC with its nuclear forces.

While the two armies kept staring at each other, other positive developments occurred over a period of years. Goodwill between the mainland and Taipei grew due to a string of decisions over a 10-year period that brought the two governments together. Under the leadership of the Kuomintang Party since 2008, particularly in the last two years under President Tang*, ties had strengthened between the peoples of the mainland and Taipei. Direct flights between mainland cities and Taiwan were introduced in 2005; in 2018, over two million mainlanders visited Taiwan, and 1.5 million Taiwanese visited the mainland. Various organizations on both sides of the Straits had grown up to identify and bring together families that had been separated at the time Chiang Kai-Shek took his supporters to Formosa. Most important of all, Taipei retained its status as an area with high Foreign Direct Investment on the mainland. There had even been goodwill visits of the Ministers of Defense to each other's countries.

The Sino Peace Treaty was essentially a statement of goodwill and intention. It reaffirmed that Taiwan was a province of the PRC and that both countries would seek to bring full unification at some still undesignated time in the future. Three sections of the Treaty were especially important. Section 1 called for each party to begin to draw down its offensive weapons targeted to the other party. Section 2 contained formulas for reducing to zero inbound and outbound tariffs between the two authorities over a ten-year period. Section 3 called for the heads of government, ministries, and military to meet annually for the purpose of building relationships between the two sides.

*Fictitious Name

\section{Appendix D}

\section{Six Assurances}

President Reagan in 1982 gave six assurances to Taiwan about his negotiations with the People's Republic of China concerning Taiwan's status:

1. The United States would not set a date for termination of arms sales to Taiwan.

2. The United States would not alter the terms of the Taiwan Relations Act.

3. The United States would not consult with China in advance before making decisions about U.S. arms sales to Taiwan.

4. The United States would not mediate between Taiwan and China.

5. The United States would not alter its position about the sovereignty of Taiwan which was, that the question was to be decided peacefully by the Chinese themselves, and would not pressure Taiwan to enter into negotiations with China.

6. The United States would not formally recognize Chinese sovereignty over Taiwan. ("The 'Six Assurances' to Taiwan," 1982)

\section{Appendix E}

\section{Three No's}

"President Bill Clinton surprised the U.S. foreign policy community, as well as U.S. friends in Taiwan, by asserting his "three no's" policy on a state visit to Shanghai in 1998. The President clarified this policy to the press" (Wortzel, 2000, para. 7).

In the words of President Bill Clinton,

I had a chance to reiterate our Taiwan policy, which is that we don't support independence for Taiwan or 'two Chinas' or 'one Taiwan, one China.' And we don't believe that Taiwan should be a member in any organization for which statehood is a requirement. (Farley \& Marshall, 1998) 